\title{
ANTI-ALZHEIMER ACTIVITY OF TACRINE LOADED METHOXYPOLY (ETHYLENE GLYCOL) POLY (CAPROLACTONE) NANOPARTICLES
}

\author{
FELIX JOE V ${ }^{1 *}$, SATHESH KUMAR $S^{2}$ \\ ${ }^{1}$ Department of Pharmaceutics, Shree Devi College of Pharmacy, Mangalore, Karnataka, India. ${ }^{2}$ Department of Pharmaceutics, \\ School of Pharmaceutical Sciences, Vels Institute of Science, Technology and Advanced Studies (VISTAS), Chennai, Tamil Nadu, \\ India. Email: felixjoev@gmail.com
}

Received: 10 October 2018, Revised and Accepted: 11 December 2018

ABSTRACT

Objective: The objective of the study was to study the in vitro cytotoxic effects of amyloid- $\beta$ (A $\beta$ ) in SH-SY5Y cells and in vivo therapeutic efficacy of drug-loaded nanoparticles (TMPCN-3) in mice.

Methods: In vitro cytotoxic effects of A $\beta$ in SH-SY5Y cells were carried out using 3-[4,5-dimethylthiazol-2-yl]-2,5 diphenyl tetrazolium bromide assay; cellular uptake study was carried using a laser scanning fluorescence microscope. The in vivo therapeutic efficacy of drug loaded nanoparticles, optimized formulation (TMPCN-3) were studied in mice. Animals $(\mathrm{n}=18)$ were divided into three different groups each consisting of six animals in each group.

Results: Treatment with A $\beta$-induced cytotoxicity showed a 54\% decrease in cell viability. Drug-treated with TMPCN-3 showed greater intracellular accumulation. In the invasive study TMPCN-3 nanoparticles, the SH-SY5Y cells (73\%) were decreased when compared to the control cells (91\%). In vivo therapeutic efficacy of drug-loaded nanoparticles was studied in mice, Morris water maze task shows polymeric nanoformulations indicates critical change execution (expanded memory maintenance) when contrasted with control, step down condition maintains a considered space from response created by the memory change and polymeric nanoformulations, and after that taken by tacrine and control the quantity of errors are higher. The nanoformulations distributed massive decreasing in acetylcholine esterase level brain homogenate.

Conclusion: Tacrine-loaded methoxypoly(ethylene glycol) poly(caprolactone) reveals that the in vitro cell line believes emphasized the reduced risk of tacrine loaded nanoparticles as there is a significant decrease half maximal inhibitory concentration and higher convention of drug in the glial cells and by in vivo reflects was confirmed that nanoformulation indicated improved memory.

Keywords: 3-[4,5-dimethylthiazol-2-yl]-2,5 diphenyl tetrazolium bromide assay, SH-SY5Y cells, Tacrine hydrochloride, $\beta$-Amyloid.

(C) 2018 The Authors. Published by Innovare Academic Sciences Pvt Ltd. This is an open access article under the CC BY license (http://creativecommons. org/licenses/by/4. 0/) DOI: http://dx.doi.org/10.22159/ajpcr.2018.v11s4.31730

\section{INTRODUCTION}

Alzheimer's disease (AD) is the most widely recognized age-related neurodegenerative issue described by the loss of neurons, extracellular broken-down plaques, and intracellular neurofibrillary tangles [1]. The inside factor of the plaques is $\beta$-amyloid peptide (amyloid- $\beta[A \beta]$ ), which is distinguished to meet up to structure "dangerous" oligomers that might be basic in starting AD pathology [2]. $A \beta$ is produced after ordered cleavage of the amyloid foreruner protein (APP) inside the transmembrane zone, in this manner, the cut peptides keep up some layer penetrating property. The amphiphilic $A \beta$ can trap specific entanglement to phospholipid bilayers with very high comparability, implying that the cell film of neurons might be an essential focus of $A \beta$ [3]. $A \beta$ have be answer to shape ionic pores, straight prompting cell expiry or setting off the apoptotic motioning among intercession with the parameter of calcium homeostasis [4]. A $\beta$ can likewise alter the physicochemical property of neuronal films (e.g., film smoothness), and initiate layer destabilization and permeabilization [5]. Both layer $A \beta$ relations and harmfulness seem, by all accounts, to be adjusted by the lipid arrangement, predominantly cholesterol, and ganglioside, which are predicted to be the real segments in the lipid-pontoon areas of the plasma film [6]. Cholesterol decrease can diminish the improvement of insoluble $A \beta$ in hippocampal neurons [7]. To study the in vitro cytotoxic effects of $(A \beta)$ in SfH-SY5Y cells and in vivo therapeutic efficacy of drug loaded nanoparticles (TMPCN-3) were carried out in mice.

\section{METHODS}

Tacrine hydrochloride was procured from Sigma-Aldrich (St. Louis, MO), SH-SY5Y cell line was procured from National Centre for Cell Science
(NCCS) Pune, India, 3-[4,5-dimethylthiazol-2-yl]-2,5 diphenyl tetrazolium bromide (MTT) was procured from Sigma-Aldrich (St. Louis, MO), and $\beta$-Amyloid was procured from Sigma-Aldrich (St. Louis, MO).

\section{Cell culture and maintenance}

SH-SY5Y cells were procured from NCCS, Pune, India. The cells were developed in Dulbecco's Modified Eagle Medium with $10 \%$ fetal bovine serum and $1 \%$ penicillin-streptomycin in humidified conditions under the conditions of $37^{\circ} \mathrm{C}$ and $5 \% \mathrm{CO}_{2}$.

\section{MTT assay}

Dissolve the MTT in Dulbecco's phosphate-buffered saline (DPBS), $\mathrm{pH}=7.4$ (DPBS) to $5 \mathrm{mg} / \mathrm{ml}$. Filter and sterilize the MTT solution through a $0.2 \mu \mathrm{M}$ and filter it into a sterile, light endangered container. The MTT solution was stored in, light protected condition at $4^{\circ} \mathrm{C}$ for numerous use. For long-term storage, the solution was stored at $-20^{\circ} \mathrm{C}$. Arrange the cells and test mixtures in 96-well plates containing a final volume of $100 \mu \mathrm{l} /$ well and were incubated. Add $10 \mu \mathrm{l}$ MTT solution per well to attain a ending concentration of $0.45 \mathrm{mg} / \mathrm{ml}$. Incubate the solution at $1-4 \mathrm{~h}$ at $37^{\circ} \mathrm{C}$. Then, add $100 \mu \mathrm{l}$ of solubilization solution to each well and dissolve the formazan crystals and mixed well to ensure complete solubilization and record the absorbance at $570 \mathrm{~nm}$ [8].

\section{Cellular uptake of drug-loaded nanoparticles}

For a qualitative study using laser scanning fluorescence microscope, SH-SY5Y cells were seeded onto 96-well plates with glass coverslips at a density of 50,000 cells per well, incubated for $24 \mathrm{~h}$ and treated with pure drug tacrine, plain nanoparticle formulation and drugtreated with TMPCN-3 at a concentration of $200 \mathrm{mg} / \mathrm{ml}$ for $4 \mathrm{~h}$. They 
were then washed with PBS and fixed using 4\% formaldehyde at room temperature for $15 \mathrm{~min}$. Subsequently, the cells were washed with PBS for 3 times and stained with Hoechst dye $(1 \mathrm{mg} / \mathrm{ml})$ for $30 \mathrm{~min}$. The cells were washed with phosphate-buffered saline for 3 times before the coverslips were mounted onto the microscope slides and visualized using an Olympus fluorescence microscope [9].

\section{Invasion assay}

SH-SY5Y cells were developed to $80 \%$ contract then serum starved overnight before set up the probe. Cells were eroded twice in DPBS and collected from the plate using 0.5 mol/L EDTA ( $\mathrm{pH}$ 6.8). The cells were composed and resuspended in malnourishment medium. We used 24-well Transwell cavities (BD Bio Coat Control Inserts from BD Biosciences) with 8.0 - $\mathrm{mm}$ pore size polycarbonate casing for this testing. The cells were covered at a density of $5 \times 10^{4}$ per well in $0.5 \mathrm{~mL}$ in the upper well, which was placed in the lower well containing with one of the following environments: Complete medium and drug at different concentrations or complete growth medium (10\% PBS), after $24 \mathrm{~h}$ at temperature of $37^{\circ} \mathrm{C}, 5 \% \mathrm{CO}_{2}$ incubator for $24 \mathrm{~h}$, the experiment was stopped by wiping the cells from the cell with a cotton swab and fixed and discolored using the Diff-Quik kit. Immigration was measured by counting 12 fields at a magnification of 400 .

\section{Body weight}

To assess in vivo toxicity of drug delivery system, the fluctuation in animal body weight is standard as a useful indicator. Here, the mice body weight was recorded for a period after the beginning of treatment, and mice infused with saline regarded as the control.

Experiments were performed with colony inbreed strains of Swiss albino mice (male) maintained at $23-25^{\circ} \mathrm{C}, 12 \mathrm{~h}$ light/dark cycle and provided food and water and ad libitum. The animals are acclimatized to the laboratory conditions for a week before the experiment and randomly divided into groups consisting of each six animals. The protocol for the animal studies mentioned below was submitted to the animal ethical committee and duly approved. Approval no: (XVI/VELS/ PCOL/03/2000/CPCSEA/IAEC/25.11.14).

\section{In vivo therapeutic efficacy of drug-loaded nanoparticles}

The mice $(n=18)$ were divided into three different groups each consisting of six mice in each group. Except for normal control group, the drug was administered through intraperitoneal route (i.p) after drug administration to all the groups. The protocol was followed for 9 days.

\section{Animal grouping}

Total number of animals used was 18 mice which was divided into three groups:

- Group-1 consists of six animals; the control group received normal saline (0.5 ml/kg b.w.p.o).

- Group-2 consists of six animals; drug group received a solution of tacrine in normal saline ( $5 \mathrm{mg} / \mathrm{kg}$ b.w.p.o)

- Group-3 consists of six animals, TMPCN-3 group received tacrine-loaded methoxypoly(ethylene glycol) poly(caprolactone) (mPEG-PCL) nanoparticles dose equivalent to $5 \mathrm{mg} /$ $\mathrm{kg}$ b.w of tacrine by peroral route.

\section{Morris water maze test}

The experiment was performed in an apparatus with a circular water tank (diameter $=100 \mathrm{~cm}$; height $=35 \mathrm{~cm}$ ). The water was filled into a distance of $15 \mathrm{~cm}$, and the temperature was maintained at $28^{\circ} \mathrm{C}$. The water was completed opaque by adding milk powder. A platform (diameter $=4.5 \mathrm{~cm}$; height $=14.5 \mathrm{~cm}$ ) was submerged 0.5 below the water surface and placed at the midpoint of one quadrant. On the $5^{\text {th }}$ day after the injection of $A \beta$, several trials were conducted. In each training trial, the time taken by the mice to escape on to the platform was recorded [10].

\section{Step down inhibitory avoidance}

The mechanical assembly is comprised of yellow acrylic material with a detail of a $500 \mathrm{~mm} \times 250 \mathrm{~mm} \times 250 \mathrm{~mm}$. The section was fitted with a progression of parallel $0.2-\mathrm{cm}$ bore bronze bars divided $10 \mathrm{~mm}$ separated. A $70 \mathrm{~mm}$ wide, $25 \mathrm{~mm}$ high, and $250 \mathrm{~mm}$ long stage were set at the focal point of the floor. In the instructional meeting, 0.4-mA, 2.0-s mixed foot shock was given for the mice instantly in the wake of venturing down and putting their four paws on the ground. In test sessions no foot shock given and advance down inactivity is marked with a cut off time of $300 \mathrm{~s}$. One preliminary advance down inhibitory avoidance in mice includes the initiation of two separate memory comprises, a short-term memory (STM), and a long-term memory (LTM). Thus, retention tests will be completed in $90 \mathrm{~min}$ to assess STM [11].

\section{Histopathological studies}

After 8-day behavior, the brains of distinct collections were perfusion fixed with $4 \%$ paraformaldehyde in $0.1 \mathrm{M}$ phosphate buffer. The brains were detached and post-fixed in the same protective overnight at $48^{\circ} \mathrm{C}$. The brains were then fixed in paraffin and discolored with HematoxylinEosin. The hippocampal lesions were evaluated microscopically at $\times 40$ exaggerations [12].

\section{Dissection and homogenization}

On day 9, after behavioral valuations, animals were sacrificed by execution before deep anesthesia. The brains were detached, forebrain was dissected out, and cerebellum was removed. Brain was put on ice and rinsed with ice-cold isotonic saline. A $(10 \% \mathrm{w} / \mathrm{v})$ homogenate was arranged in $0.1 \mathrm{M}$ phosphate buffer ( $\mathrm{pH} 7.4$ ). The homogenate was centrifuged at 10,000 g for $15 \mathrm{~min}$, and aliquots of supernatant were separated and used for biochemical assessment [12].

\section{Acetylcholinesterase (AChE) activity}

The AChE activity estimation was performed by Ellman's method. The esterase activity is done by the synthetic substrate, acetylthiocholine (ATC). AChE is made to catalyzed with the -SH reagent 5,5'-dithiobis(2-nitrobenzoic acid), and it is condensed to a yellow colored anion - thionitrobenzoic acid, the concentration maxima of this compound is $412 \mathrm{~nm}$. The absorption of thionitrobenzoic acid identified using an ultraviolet spectrophotometer. The esterase activity was slow by providing a synthetic substrate, ATC [13].

\section{RESULTS}

\section{In vitro cell line studies}

MTT assay

MTT cell viability test was accomplished to determine the cytotoxicity of TMPCN-3 nanoparticles in SH-SY5Y cells. The half maximal inhibitory concentration $\left(\mathrm{IC}_{50}\right)$ value of the pure drug, plain nanoformulation, and TMPCN-3 was found to be $6.9 \mu \mathrm{g},>100 \mu \mathrm{g}$, and $4.3 \mu \mathrm{g}$ TMPCN-3 nanoformulation which showed that enhanced in the reduction of the $\mathrm{IC}_{50}$ value of TMPCN-3 nanoformulation. The plain nanoparticles did not display serious cytotoxicity in which cell viability of $>73 \%$ was achieved in SH-SY5Y cells. The graphical representation of percentage cell viability for plain nanoparticles and drug-loaded with mPEG-PCL (TMPCN-3) nanoformulation was shown in Figs. 1 and 2.

Cellular uptake of drug-loaded nanoparticles (Hoechst dye) The uptake of TMPCN-3 nanoparticles in SH-SY5Y cells was analyzed by fluorescence magnifying lens. Cells treated with TMPCN-3

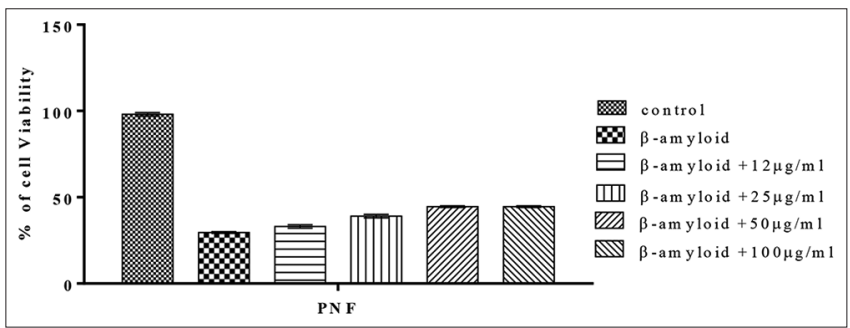

Fig. 1: Percentage of cell viability of plain nanoformulation 
demonstrated higher intracellular accumulation. The properties of drug-loaded nanoparticle were shown in Fig. 3.

\section{Invasion study}

As shown in Fig. 4, there is a critical drop in the capacity of the treated cells to move into the unfilled space related with control in SH-SY5Y cells, and the amount of cells crossed Matrigel in the drug behavior was significantly reduced when compared with control cells. SH-SY5Y cells were diminished in the TMPCN-3 nanoparticles. This outcome suggested that TMPCN-3 treatment exhibited a substantial effect on the cellular viability and it inhibited the invasion in SH-SY5Y cells.

\section{In vivo studies}

The step-down condition maintains a calculated distance from reaction created by the memory change. Polymeric nanoformulations, and subsequently taken by tacrine and control the quantity of errors is higher as shown in Fig. 5

The brain homogenate produced the absorbances/min is higher in control and followed by standard, and then the nanoformulations produced a substantial decrease in acetylcholine esterase level in brain homogenate as shown in Fig. 6.

The control considerably delayed mean latency and retention mean latency, which leads to produce the cognitive impairment. The polymeric nanoformulations showed significant improvement performance (increased memory retention) as shown in Fig. 7.

\section{DISCUSSION}

$\mathrm{AD}$ is a dynamic neurodegenerative issue. The pathology of $\mathrm{AD}$ is described by abnormal accumulation of the proteins $A \beta$ and hyperphosphorylated tau [14].The impact of RS4252 on amyloid $\beta 1-40$ prompted restraint of MTT decrease and found that RS-4252 can possibly altogether enhance the amyloid $\beta_{1}-40$ incited cytotoxicity. The compound has the profile of a $\beta$-sheet breaker since hindrance of fibril arrangement is one of the conceivable remedial treatment for Alzheimer's ailment. HeLa cells demonstrated a significant level of phosphorylated protein kinase-B without amyloid $\beta_{1}-40$ after brooding with MTT for $30 \mathrm{~min}$. The aggregate sum of protein kinase-B does not change in any of the groups [15].The size and number of vacuoles indicated a positive association with $A \beta$ focus and term of $A \beta 42$ treatment by $A \beta 42$, cells developed regularly to conversion despite the fact that there was across the board arrangement of cytoplasmic vacuoles. There was no reduction on the cell film inside the day and age tried despite the fact that treatment of $\mathrm{A} \beta 42$ for $72 \mathrm{~h}$ brought about cell

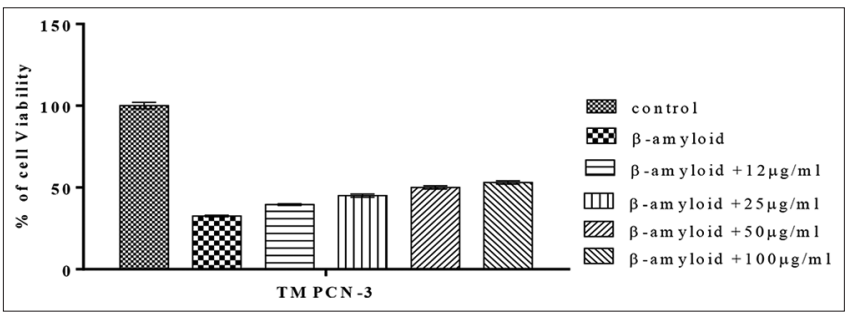

Fig. 2: Percentage of cell viability of TMPCN-3

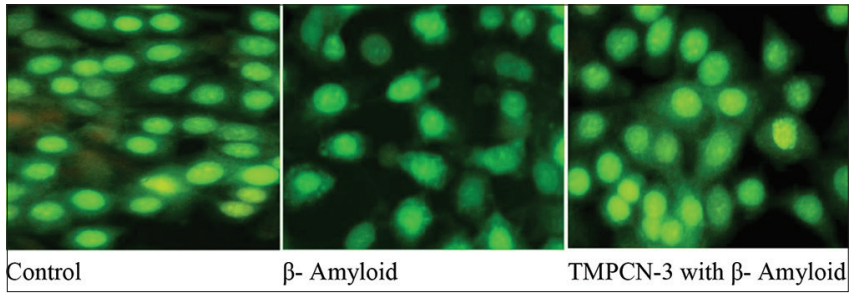

Fig. 3: Cellular uptake studies of TMPCN-3 formulations damage related with down-directed metabolic capacity. Hindrance on the decrease framework or the esterase movement is a generally late and genuine occasion related with diminish in cell feasibility that may be known to the perpetual cytotoxicity due to long-hatching with expanded measure of $\mathrm{A} \beta 42$, like the constant neurodegeneration caused in any event mostly by the expansion of harmful $A \beta 42$ in $A D$ patients' cerebrum [16]. For all fibrillar arrangements, there was a noteworthy abatement in MTT decrease at $0.01 \mu \mathrm{M}$ protein (conversely, treatment of the cardiomyocytes with non-fibrillar $\mathrm{rV} \lambda 6$ proteins brought about a maximal $15 \%$ lessening in MTT decrease at $1 \mu \mathrm{M}$ protein, in respect to control). Non-amyloid elastin fibrils required $1 \mu \mathrm{M}$ protein to cause a huge $25 \%$ decline in MMT to decrease [17]. The cell nanoparticles take-up in general change of medication ingestion or focusing on conveyance stays unclear. Nanoparticles take-up ponders saw in Caco-2 cells could be considered to connect with in vivo circumstances. These demonstrate that piece of nanoparticles take-up on bioavailability change of little atoms is restricted, and the level of nanoparticles ingested by means of, the nanoparticles transcytosis component. Impressively more noteworthy tissue take-up for biodegradable nanoparticles, for example, poly lactic-poly glycolic corrosive copolymer nanoparticles and lecithin-covered nanoparticles have been observed [18]. The utilization of these center shell nanospheres as another fluorescent cell tracker test for predominant in vitro and in vivo imaging due to their extraordinary optical properties. The cytotoxic impacts of the LFCSNs on the mitochondrial movement of cells were expanded in connection to the expanding LFCSNs focus. LFCSNs at on a grouping of $640 \mathrm{lg} / \mathrm{mL}$ can be considered to have low cytotoxicity [19]. The inclusion of phospholipid into AOT-alginate nanoparticles enhance their uptake/intracellular accumulation, and metabolic restraint ponders proposed that phone disguise of nanoparticles is interceded by endocytosis. The nanoparticles are disguised by the folate receptor-interceded endocytosis component; endocytosis pathway may result in an imperative increment in the cell

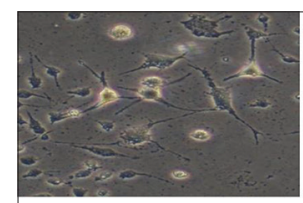

$\beta$-Amyloid

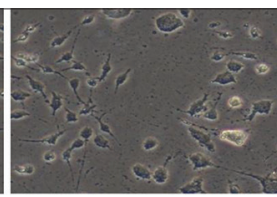

$\beta$-Amyloid $+12 \mu \mathrm{g} / \mathrm{ml}$

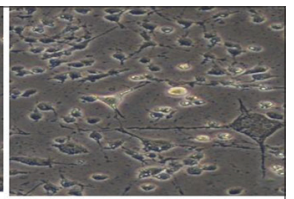

$\beta$-Amyloid $+25 \mu \mathrm{g} / \mathrm{ml}$

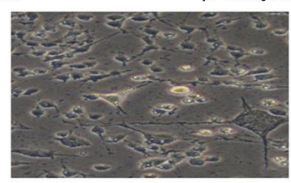

B-Amyloid $+50 \mu \mathrm{g} / \mathrm{ml}$

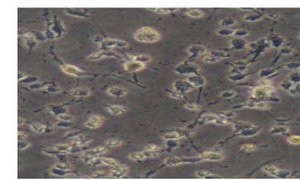

B-Amyloid $+100 \mu \mathrm{g} / \mathrm{m}$
Fig. 4: Invasive study for TMPCN-3 formulations

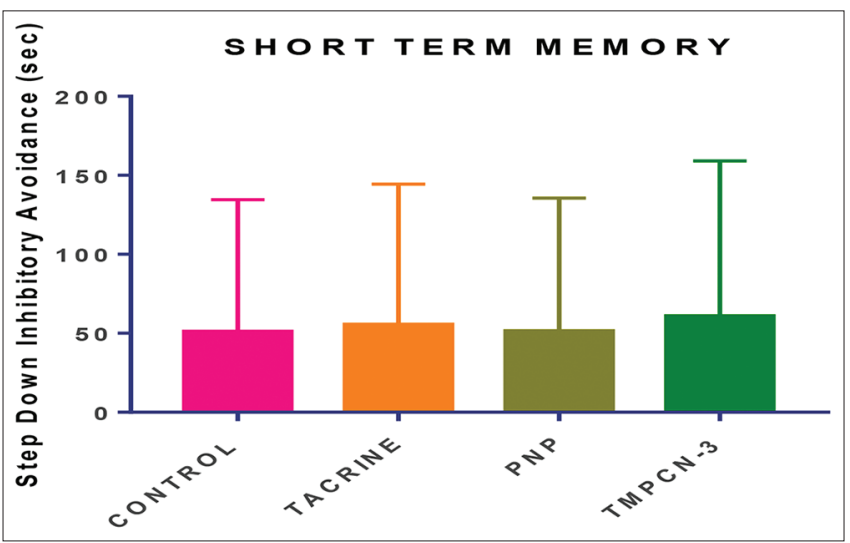

Fig. 5: Scopolamine-induced memory deficits in inhibitory stepdown avoidance 


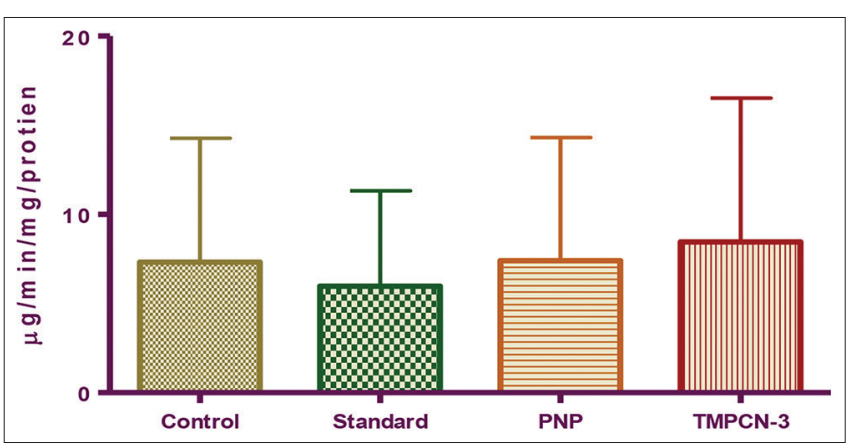

Fig. 6: Scopolamine-induced acetylcholine esterase level in brain

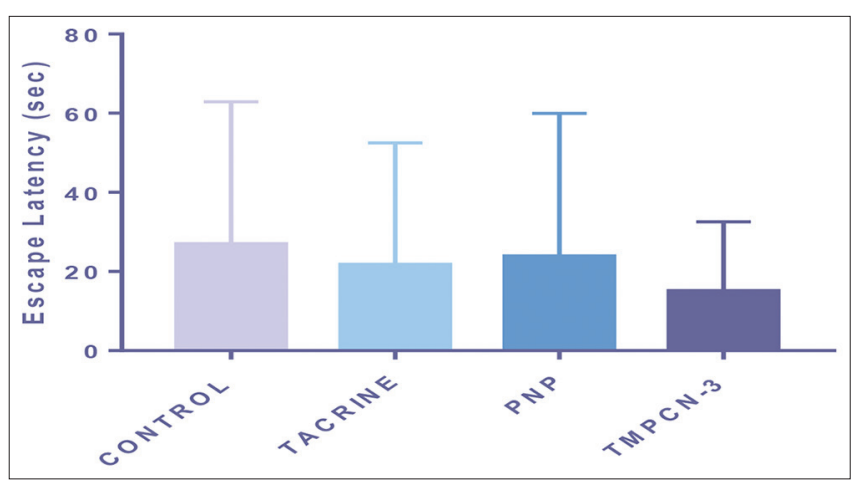

Fig. 7: Scopolamine-induced memory deficits in Morris water maze task

take-up productivity. The cell relationship of nanoparticles was entirely different relying on their physicochemical highlights and kind of the cell line [20]. Moreover, bio-impedance and electrical conduction additionally is impacted by on "additional mortal components", for example, soil interceded between the paws and the bars amid tests, and another factor hard to gauge. The estimation and record the present transient in animals, if any additional physical elements diminish the present force. The conduct reaction to the boost is more extraordinary at higher frequencies. Step-down inhibitory avoidance gadget expected by the animal through the paws was definitely a similar current connected with no intercession of the body for bioimpedance for all boosts powers [21]. Rats indicated precise memory in which they got foot shock. Continued testing of similar creatures in both inhibitory evasion devices immediately is a precise strategy for assessing knowledge in significant rats. They were not able to recollect in which of the two preparing settings they had gotten real foot shock on the grounds that related long maintenance latencies in the shock and nonshock boxes were caused [22]. Rats prepared with $0.5 \mathrm{~mA}$ - i.e., a gentle over edge footshock-90 min after 3-min investigation after the past, did not indicate extensive changes in execution for STM. Higher measurements of scopolamine were important to debilitate memory. Scopolamine would influence the tactile view and consideration at bring down measurements $(0.1 \mathrm{mg} / \mathrm{kg})$, and learning and memory at higher dosages $(4 \mathrm{mg} / \mathrm{kg}$ ) [23]. Total cortical AChE movement was significantly brought down by $29 \%$ in the tween-infused mice contrasted and the unhandled mice, yet there were no distinctions in the solvent cortical AChE action. A comparative event was seen in the hippocampus where add up to AChE levels were additionally brought down by $20 \%$ in the vehicle-infused mice. If there should be an occurrence of midbrain, there were no distinctions in complete AChE behavior between the two gatherings; however, dissolvable AChE action was essentially high in the took care of vehicle-infused assemble [24]. The elevated cholesterol eating routine gathering of mice showed impressively impeded LTM contrasted with the control animals which were clear from the segregation list score of question acknowledgment memory tests [25]. The catalysts hindrance might be fundamentally influenced by $\mathrm{pH}$, in the irreversible no not as much as the reversible case. The rate response of the inhibitor with the catalyst might be influenced by $\mathrm{pH}$ on the grounds that the diverse ionic types of the protein may respond at various rates with the inhibitor [26]. Injured movement was higher in the cerebrum of both ordinary and alloxan diabetic rats when contrasted with alternate districts of the notice. Both the grown-up and matured mice of control and focused on bunches demonstrated extensive learning. In charge and focused on mice were directed in both untrained (not subjected to uninvolved shirking test) and in addition prepared (latent evasion test) gathering of grown-up and matured [27]. AChE degrades the neurotransmitter acetylcholine, creating choline, and an acetic acid derivation gathering. In brain activities changes of antioxidant enzymes, glutathione and thiobarbituric acid reactive substances contents in all the experimental groups of rat [28]. In intense organizations of L-tyrosine in 10 and 30-day-old rats indicated expanded AChE action in serum and all assessed cerebrum zones when contrasted with control bunch [29]. The impact of zinc chloride, cadmium acetic acid derivation, mercury chloride, and lead acetic acid derivation was examined. Hurt movement in zebra fish mind. In spite of the fact that a slight enlarge of the movement after $24 \mathrm{~h}$ overview, zinc chloride did not impact the chemical activity. So also to zinc chloride, cadmium acetic acid derivation does not adjust the protein movement in the fixation tried [30]. For spatial learning one of the better measures proposed was estimating the aggregate separation. Different measures are time or separation in the objective annulus (the space between two concentric circles), characterized by lines moving the outside and inside edges of the stage, separately. The amount of direct swims (number of paths within a preset corridor from the start to the goal) or circle swims (a swim trajectory that approximates a decreasing radius arc of a circle from the start point to the hidden platform and circling is less than $360^{\circ}$ ), jump-offs, deflections, swim overs. Alternate measures are essential particularly when testing creatures that have been as of late regulated a medication that can disturb sensorimotor capacity [31]. The hippocampus is engaged with spatial memory. There are a few different parts of the undertaking that do not draw in spatial memory: The pressure required with the assignment, the comprehension of the standards of the errand. Hormones effects affect hippocampal subordinate errand execution, hippocampal life systems, and hippocampal cell work. A few conditions are low estradiol and progesterone, high estradiol and progesterone, and middle estradiol and progesterone in testing solitary animals [32]. Examination of escape idleness, the time the mouse took to locate the concealed stage, uncovered a noteworthy reduction after some time in the securing stage. Expanded dependence on spatial systems to find the stage is solid with the arrangement a psychological spatial. Mice had been prepared with four preliminaries for each day invested more energy in the stage quadrant than in all others. This demonstrates running improves securing on the water maze task. Increased neurogenesis in the sprinters adds to learning. A few different components that advance generation of new neurons are likewise related with improved learning [33]. Treatment with hormones, for example, estrogen, expands cell expansion, and enhances memory work. The variables that decrease neurogenesis, for example, corticosterone treatment, stress, and maturing, are connected with lessened execution on spatial learning assignments [34]. In vitro cytotoxicity assay, the violacein exhibits significant activity against A549 lung cancer cell line [35]. ethanolic extract has no cytotoxic activity, and the other extracts had moderate to weak cytotoxic activity on (NIH 3T3) and HeLa cell lines using MTT assay [36]. Human neuroblastoma SH-SY5Y cells, some carboline alkaloids induce apoptosis as well as necrosis [37].

\section{CONCLUSION}

The prepared tacrine-loaded mPEG-PCL reveals that the in vitro cell line studies confirmed the reduced toxicity of tacrine-loaded nanoparticles as there are a significant reduction IC $_{50}$ value and higher aggregation of the drug in the glial cells and by in vivo studies it was confirmed that nanoformulation showed enhanced memory. Furthermore, patient 
studies are required for the prepared drug delivery system.

\section{REFERENCES}

1. Huang Y, Mucke L. Alzheimer mechanisms and therapeutic strategies. Cell 2012;148:1204-22.

2. Haass C, Selkoe DJ. Soluble protein oligomers in neurodegeneration: Lessons from the Alzheimer's amyloid beta-peptide. Nat Rev Mol Cell Biol 2007;8:101-12.

3. Arispe N, Pollard HB, Rojas E. Beta-amyloid ca(2+)-channel hypothesis for neuronal death in Alzheimer disease. Mol Cell Biochem 1994;140:119-25.

4. Dong Z, Saikumar P, Weinberg JM, Venkatachalam MA. Calcium in cell injury and death. Annu Rev Pathol 2006;1:405-34.

5. Grösgen S, Grimm MO, Friess P, Hartmann T. Role of amyloid beta in lipid homeostasis. Biochim Biophys Acta 2010;1801:966-74.

6. Yu X, Zheng J. Cholesterol promotes the interaction of Alzheimer $\beta$-amyloid monomer with lipid bilayer. J Mol Biol 2012;421:561-71.

7. Schneider A, Schulz-Schaeffer W, Hartmann T, Schulz JB, Simons M. Cholesterol depletion reduces aggregation of amyloid-beta peptide in hippocampal neurons. Neurobiol Dis 2006;23:573-7.

8. Cui Y, Xu Q, Chow PK, Wang D, Wang CH. Transferrin-conjugated magnetic silica PLGA nanoparticles loaded with doxorubicin and paclitaxel for brain glioma treatment. Biomaterials 2013;34:8511-20.

9. Li Y, He H, Jia X, Lu WL, Lou J, Wei Y, et al. A dual-targeting nanocarrier based on poly(amidoamine) dendrimers conjugated with transferrin and tamoxifen for treating brain gliomas. Biomaterials 2012;33:3899-908

10. Morris R. Developments of a water-maze procedure for studying spatial learning in the rat. J Neurosci Methods 1984;11:47-60.

11. Barros DM, Ramirez MR, Izquierdo I. Modulation of working, short-and long-term memory by nicotinic receptors in the basolateral amygdala in rats. Neurobiol Learn Mem 2005;83:113-8.

12. Yu Z, Cheng G, Hu B. Mechanism of colchicine impairment on learning and memory, and protective effect of CGP36742 in mice. Brain Res 1997;750:53-8.

13. Sedlak J, Lindsay RH. Estimation of total, protein-bound, and nonprotein sulfhydryl groups in tissue with ellman's reagent. Anal Biochem 1968;25:192-205.

14. Ismail R, Hansen AK, Parbo P, Brændgaard H, Gottrup H, Brooks DJ, et al. The effect of 40-hz light therapy on amyloid load in patients with prodromal and clinical Alzheimer's disease. Int J Alzheimers Dis 2018;2018:6852303.

15. Nishimura S, Murasugi T, Kubo T, Kaneko I, Meguro M, Marumoto S, et al. RS-4252 inhibits amyloid beta-induced cytotoxicity in HeLa cells. Pharmacol Toxicol 2003;93:29-32.

16. Liu ML, Hong ST. Early phase of amyloid $\beta 42$-induced cytotoxicity in neuronal cells is associated with vacuole formation and enhancement of exocytosis. Exp Mol Med 2005;37:559-66.

17. McWilliams-Koeppen HP, Foster JS, Hackenbrack N, RamirezAlvarado M, Donohoe D, Williams A, et al. Light chain amyloid fibrils cause metabolic dysfunction in human cardiomyocytes. PLoS One 2015; 10:e0137716.

18. Lai Y, Chiang PC, Blom JD, Li N, Shevlin K, Brayman TG, et al. Comparison of in vitro nanoparticles uptake in various cell lines and in vivo pulmonary cellular transport in intratracheally dosed rat model. Nanoscale Res Lett 2008;3:321-9.

19. Ansari AA, Hasan TN, Syed NA, Labis JP, Alshatwi AA. In-vitro cytotoxicity and cellular uptake studies of luminescent functionalized core-shell nanospheres. Saudi J Biol Sci 2017;24:1392-403.

20. Salatin S, Yari Khosroushahi A. Overviews on the cellular uptake mechanism of polysaccharide colloidal nanoparticles. J Cell Mol Med 2017;21:1668-86

21. Borba Filho GL, Zenki KC, Kalinine E, Baggio S, Pettenuzzo L, Zimmer ER, et al. A new device for step-down inhibitory avoidance task-effects of low and high frequency in a novel device for passive inhibitory avoidance task that avoids bioimpedance variations. PLoS One 2015;10:e0116000.

22. Atucha E, Roozendaal B. The inhibitory avoidance discrimination task to investigate accuracy of memory. Front Behav Neurosci 2015;9:60.

23. Colettis NC, Snitcofsky M, Kornisiuk EE, Gonzalez EN, Quillfeldt JA, Jerusalinsky DA, et al. Amnesia of inhibitory avoidance by scopolamine is overcome by previous open-field exposure. Learn Mem 2014;21:634-45.

24. Appleyard ME, Taylor SC, Little HJ. Acetylcholinesterase activity in regions of mouse brain following acute and chronic treatment with a benzodiazepine inverse agonist. Br J Pharmacol 1990;101:599-604.

25. Paul R, Borah A. Global loss of acetylcholinesterase activity with mitochondrial complexes inhibition and infammation in brain of hypercholesterolemic mice. Sci Rep 2017;7:17922

26. Costa M, Bernardi J, Costa L, Fiuza T, Brandao R, Pereira M. N-acetyl cysteine decreases mice brain acetyl cholinesterase activity: An in vitro kinetic study. Enz Eng 2015;5:1-6.

27. Ahmed N, Tarannum S. Acetylcholinesterase activity in the brain of alloxan diabetic albino rats: Presence of an inhibitor of this enzyme activity in the cerebral extract. Int J Diabetes Dev Ctries 2009;29:174-7.

28. Khan RA, Khan MR, Sahreen S. Brain antioxidant markers, cognitive performance and acetylcholinesterase activity of rats: Efficiency of Sonchus asper. Behav Brain Funct 2012;8:21

29. Ferreira GK, Carvalho-Silva M, Gonçalves CL, Vieira JS, Scaini G, Ghedim FV, et al. L-tyrosine administration increases acetylcholinesterase activity in rats. Neurochem Int 2012;61:1370-4.

30. Richetti SK, Rosemberg DB, Ventura-Lima J, Monserrat JM, Bogo MR, Bonan $\mathrm{CD}$, et al. Acetylcholinesterase activity and antioxidant capacity of zebrafish brain is altered by heavy metal exposure. Neurotoxicology 2011;32:116-22.

31. Vorhees CV, Williams MT. Morris water maze: Procedures for assessing spatial and related forms of learning and memory. Nat Protoc 2006;1:848-58.

32. Nunez J. Morris water maze experiment. J Vis Exp 2008;19:897.

33. Snow WM, Pahlavan PS, Djordjevic J, McAllister D, Platt EE, Alashmali S, et al. Morris water maze training in mice elevates hippocampal levels of transcription factors nuclear factor (erythroid-derived 2)-like 2 and nuclear factor kappa B p65. Front Mol Neurosci 2015;8:70.

34. van Praag H, Christie BR, Sejnowski TJ, Gage FH. Running enhances neurogenesis, learning, and long-term potentiation in mice. Proc Natl Acad Sci U S A 1999;96:13427-31.

35. Vishnu TS, Palaniswamy M. Evaluation of In vitro cytotoxic effect of Violacein produced by novel isolate chromobacterium vaccinii CV5 against the cervical and lung cancer cell. Asian J Pharm Clin Res 2017; 10:227-29.

36. Habeela JN, Raja MMMK. In vitro cytotoxic and Apoptosis study of chemical constituents from Clerodendrum Phlomidis leaf on MCF-7 and A549 cancer cell lines. Asian J Pharm Clin Res 2018;11:229-04.

37. Purvi HK, Harish NK,Manan R. cytotoxic effect of Corchorus depressus against HEPG2 and HLE human liver cancer cells. Asian J Pharm Clin Res 2018;11:187-89. 